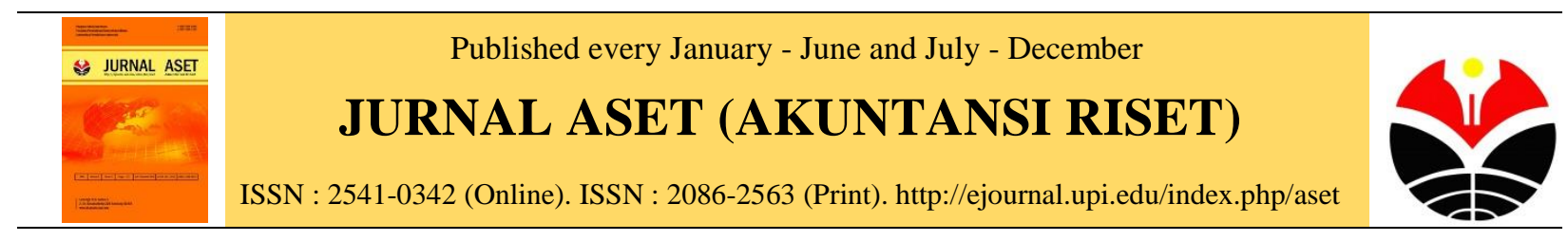

\title{
Pengaruh Inflasi, Bunga dan Nilai Tukar Terhadap Harga Saham (Studi Pada : Perusahaan Sektor Properti Dan Real Estate Tercatat BEI)
}

\author{
Bambang Susanto \\ Jurusan Akuntansi, Fakultas Ekonomi, Universitas Sangga Buana YPKP, Bandung, Indonesia.
}

\begin{abstract}
This research to find out the correlation between Inflation rate, Exchange Rate and Interst Rate to Stock Price of Property and Real Astate Sector listed on Indonesia Stock Exchange. The result of the research is $F$ calculate 2,167 while F table 1,53125, it can be concluded that all independent variables in this research influence the dependen variable simultantly. As for the partial test obtained the result that Inflation did not significantly affect the stock price of property sector and real astate in the year of observation. While the variable of interest rate and exchange rate have significant effect.
\end{abstract}

Keywords. Inflation; interest rate; exchange rate; stock price.

Abstrak. Investor perlu mengetahui kemampuan perusahaan dan prospek perusahaan Penelitian ini dilakukan untuk mengetahui hubungan antara tingkat Inflasi, Nilai Tukar dan Tingkar Bunga terhadap Harga Saham sektor Properti dan Real Astate yang terdaftar di Bursa Efek Indonesia. Hubungan yang dicari dalam penelitian ini adalah hubungan yang bersifat parsial (Uji t) maupun simultan (Uji F)antara Tingkat Inflasi, Nilai Tukar, Tingkat bunga terhadap harga saham. . Hasil penelitian diperoleh F hitung sebesar 2,167 sedangkan F tabel sebesar 1,53125 ,maka dapat disimpulkan bahwa seluruh variabel Independen dalam penelitian ini secara bersama-sama mempengaruhi variabel Dependen. Sedangkan untuk uji parsial diperoleh hasil bahwa Inflasi tidak berpengaruh secara signifikan terhadap harga saham sektor properti dan real astate pada tahun pengamatan. Sedangkan variabel Tingkat bunga dan Nilai Tukar berpengaruh signifikan.

Kata Kunci. Inflasi; tingkat bunga; nilai tukar; harga saham.

Corresponding author. J1. PHH Mustofa (Suci) No 68. Kota Bandung. Provinsi Jawa Barat. Email: bambangsusanto18@gmail.com

How to cite this article. Susanto. (2015). Pengaruh Inflasi, Bunga dan Nilai Tukar Terhadap Harga Saham (Studi Pada : Perusahaan Sektor Properti Dan Real Estate Tercatat Bei). Jurnal Aset (Akuntansi Riset). Program Studi Akuntansi Fakultas Pendidikan Indonesia Universitas Pendidikan Indonesia, 7 (1), 29-38. Retrieved from http://ejournal.upi.edu/index.php/aset

History of article. Received: Januari 2015, Revision: Maret 2015, Published: Juni 2015 


\section{PENDAHULUAN}

Harga saham merupakan cerminan dari nilai perusahaan bagi para investor. Dimana investor akan membuat keputusan dalam membeli suatu saham kemudian menjualnya kembali. Harga saham yang cukup tinggi akan memberikan return bagi para investor berupa capital gain. Salah satu alat analisis untuk meramalkan perubahan harga saham adalah analisis variabel makro dengan melihat perubahan inflasi, suku bunga dan nilai tukar mata uang yang dapat membantu investor dalam membuat keputusan investasi yang tepat dan menguntungkan.

Kinerja saham sektor properti dan konstruksi sampai dengan Desember 2014 tumbuh sangat cemerlang, tumbuh $73,11 \%$ atau tertinggi di bursa efek Indonesia (BEI). Saham agribisinis secara tahunan (yoy) memang masih minus 3,92\%, sektor pertambangan menguat $2,85 \%$, saham sektor barang konsumsi positif menguat $8,19 \%$, dan saham sektor insfrastruktur plus 8,64\%. Saham sektor properti, keuangan, perdagangan dan jasa menjadi tiga saham dengan kenaikan tertinggi yaitu $32,5 \%, 18,05 \%, 12,98 \%$.

Perubahan inflasi yang terjadi menjadi salah satu faktor bagi para investor dalam mengambil keputusan untuk membeli suatu saham. Inflasi yang tinggi menimbulkan persepsi masyarakat dimana harga-harga mengalami kenaikan. Dalam berinvestasi investor cenderung menghindari resiko yang besar bila terjadi inflasi yang tinggi, dimana keadaan ekonomi dalam suatu Negara sedang tidak stabil, karena investor akan berhati-hati dalam berinvestasi.

Suku bunga BI Rate sebagai suku bunga acuan menjadikan sinyal perubahan suku bunga perbankan seperti suku bunga deposito dan kredit. Dengan melihat naik turunnya suku bunga BI Rate, menjadikan hal tersebut sebagai acuan bagi para investor untuk memperkirakan naik turunnya suku bunga perbankan. Kenaikan atau penurunan suku bunga BI rate tersebut menjadi sinyal naik atau turunnya suku bunga deposito dan kredit perbankan. Jika suku bunga deposito meningkat investor cenderung akan menjual sahamnya dan beralih investasi pada deposito.
Penjualan harga saham secara besar-besaran dapat menjatuhkan harga saham.

Perubahan nilai tukar dollar AS terhadap rupiah dapat menjadi salah satu analisis investor untuk melihat keadaaan ekonomi suatu Negara. Sebab jika nilai tukar suatu negara tersebut sedang membaik, hal tersebut menjadi daya tarik untuk investor dalam membeli saham pada bursa yang sedang berlangsung karena jika nilai tukar suatu Negara sedang melemah investor tidak mau mengambil resiko yang tinggi dalam menginvestasikan dananya. Jika laju inflasi yang tinggi, suku bunga yang tinggi serta rupiah yang melemah akan berdampak pada investasi di pasar modal khususnya sektor properti dan real estate.

Berdasarkan latar belakang diatas, maka rumusan masalah yang dapat diidentifikaskan adalah bagaimana pengaruh inflasi, suku bunga BI Rate, nilai tukar dollar AS secara simultan maupun parsial terhadap harga saham sektor properti periode Januari 2013 Desember 2014 di Bursa Efek Indonesia.

\section{KAJIAN LITERATUR}

Dalam melakukan investasi di pasar modal investor memerlukan informasi dalam mengambil keputusan . Investor memerlukan suatu alat analisis untuk menentukan apakah saham tersebut tepat untuk dibeli. Analisis ekonomi merupakan salah satu analisis yang dapat dilakukan investor dalam mengambil keputusan investasinya. Investor yang dapat mengestimasi datangnya perubahan faktor makro ekonomi akan mampu bertindak terlebih dahulu dalam membuat keputusan jual beli saham, dan akan memperoleh keuntungan lebih besar daripada investor yang terlambat dalam mengambil keputusan jual beli saham.

\section{Inflasi}

Inflasi merupakan perhatian utama bagi investor. Secara luas, investor akan takut terhadap inflasi yang signifikan terutama jika tidak dapat diramalkan. Dengan tingginya inflasi, maka harga saham cenderung akan turun karena adanya dorongan harga-harga 
barang meningkat sehingga daya beli investor pun akan menurun, sebaliknya jika inflasi rendah, harga saham akan meningkat karena daya beli investor yang tinggi sehingga permintaan terhadap saham pun meningkat dan mendorong pergerakan harga saham untuk naik. Hal tersebut sejalan dengan yang dijelaskan oleh Tandelilin (2010), peningkatan inflasi secara relatif merupakan sinyal negatif bagi pemodal di pasar modal.

\section{Indikator Inflasi}

Menurut Sukirno (2006), untuk mengukur tingkat inflasi, indeks harga yang selalu digunakan adalah indeks harga konsumen, atau lebih dikenal dengan istilah: consumer Price Index (CPI) yaitu indeks harga dari barang-barang yang selalu digunakan para konsumen. Menghitung tingkat inflasi IHK dapat dilakukan perhitungan sebagai berikut :

$$
\text { Inflasi }=\frac{I H K n-I H K o}{I H K o} \times 100 \%
$$

Dimana:

IHKn = Indeks Harga Konsumen saat ini

IHKo = Indeks Harga Konsumen periode lalu

\section{Suku Bunga}

Pengertian suku bunga menurut kasmir (2008) menjelaskan bahwa bunga bank dapat diartikan sebagai balas jasa yang diberikan oleh bank yang berdasarkan prinsip konvensional kepada nasabah yang membeli atau menjual produknya. Bungan juga dapat diartikan sebagai harga yang harus dibayar kepada nasabah (yang memiliki simpanan) dengan yang harus dibayar kepada bank (nasabah yang memperoleh pinjaman). Sedangkan menurut Case dan Fair (2007), tingkat bunga adalah pembayaran bunga yang dinyatakan dalam persentase pinjaman. Sedangkan bunga adalah pembayaran yang dilakukan dari penggunaan uang. Dari definisi suku bunga dari beberapa ahli diatas maka dapat diketahui bahwa suku bunga adalah suatu angka dalam bentuk presentase untuk membayar sejumlah uang yang dipinjam..

\section{Suku Bunga BI Rate}

Menurut Widiatmojo (2007), suku bunga BI Rate adalah suku bunga untuk menaggapi perubahan inflasi dan nilai tukar rupiah sebagai acuan untuk suku bunga perbankan seperti suku bunga tabungan dan deposito. Bank Sentral atau Bank indonesia memliki otoritas dalam mengubah suku bunga secara umum. Biasanya bank Indonesia akan mengubah suku bunga BI rate atau SBI (Sertifikat Bank Indonesia) untuk menanggapiperubahan inflasi. Jika inflasi tinggi atau nilai tukar rupiah merosot, baisanya Bank Indonesia akan menaikkan BI rate dan SBI. Peningkatan suku bunga BI rate atau SBI harus dilakukan BI, agar masyarakat tetap bersedia menabung di bank. Demikian pula ketika nilai tukar rupiah merosot terhadap mata uang kuat, seperti dollar AS, maka BI harus menaikkan suku bunga BI rate atau SBI, agar diikuti oleh industri perbankan. Jika tidak dilakukan, maka masyarakat akan mencairkan tabungannya untuk ditukarkan dengan dollar AS. Perubahan suku bunga bank itu akan berdampak pada instrumen investasi keuangan lainnya, seperti saham dan obligasi.

\section{Nilai Tukar Dollar AS}

Menguatnya nilai mata uang suatu Negara terhadap Negara lain dapat menandakan bahwa keadaan ekonomi Negara tersebut sedang baik. Madura (2007) menjelaskan bahwa nilai tukar atau kurs mengukur nilai suatu valuta dari perspektif valuta lain. Sedangkan dalam Mankiw (2006), nilai tukar adalah nilai yang digunakan seseorang saat menukar mata uang suatu Negara dengan mata uang Negara lain.

Menurut Sukirno (2006), nilai tukar atau kurs adalah perbandingan nilai mata uang suatu negara dengan mata uang negara lainnya. Kurs valuta asing dapat juga didefinisikan sebagai jumlah uang domestik yang dibutuhkan, yaitu banyaknya rupiah yang dibutuhkan, untuk memperoleh satu unit mata uang asing. Sedangkan kurs Bank Indonesia adalah kurs acuan transaksi rupiah terhadap mata uang asing lainnya. Dari beberapa definisi mengenai nilai tukar diatas maka dapat 
diketahui bahwa nilai tukar adalah kesepakatan nilai /tingkat harga dari suatu mata uang dengan mata uang Negara lain.

\section{Harga Saham}

Seorang investor yang ingin berinvestasi di pasar modal yang berupa saham, harus mengetahui terlebih dahulu harga saham untuk menentukan pembelian saham pada suatu perusahaan. Selembar saham mempunyai nilai atau harga, suatu harga tersebut dapat dibedakan menjadi beberapa jenis. Dalam praktiknya terdapat beberapa saham yang diperdagangkan dibedakan menurut cara peralihan dan manfaat yang diperoleh bagi pemegang saham. Menurut Rusdin (2005), nilai saham terbagi atas tiga jenis yaitu:

\section{Nilai Nominal (Nilai Pari)}

Merupakan nilai yang tercantum di dalam sertifikat saham yang bersangkutan, di indonesia saham yang duterbitkan harus memiliki nilai nominal dan untuk satu jenis saham yang sama pada suatu perusahaan harus memiliki satu jenis nilai nominal.

2. Nilai Dasar

Pada prinsip harga dasar saham ditentukan dalam harga perdagangan saat saham tersebut diterbitkan, harga dasar ini akan berubah sejalan dengandilakukannya berbagai tindakan emiten yang berhubungan dengan saham, antara lain: right Issue, Stock Split, Warran, dll.

3. Nilai Pasar

Merupakan harga suatu saham pada pasar yang sedang berlangsung, jika bursa sudah tutup maka harga sahamtersebut adalah harga penutupannya

\section{METODOLOGI PENELITIAN}

Metode penelitian yang digunakan adalah metode survey dan jenis metode yang digunakan adalah metode deskriptif verifikatif, Menurut Nazir (2003:55) Metode deskriptif adalah metode penelitian untuk membuat gambaran mengenai situasi atau kejadian, sehingga metode ini berkehendak mengadakan akumulasi data dasar belaka, sedangkan menurut Mashuri metode verifikatif adalah memeriksa benar tidaknya apabila dijelaskan untuk menguji suatu cara dengan atau tanpa perbaikan yang telah dilaksanakan di tempat lain dengan mengatasi masalah yang serupa dengan kehidupan (Nazir,2008:45).

Data penelitian merupakan data sekunder berupa berupa data inflasi IHK, suku bunga BI rate, nilai tukar dollar AS terhadap rupiah yang diperoleh dari website Bank Indonesia serta data harga saham sektor properti dan real estate yang diperoleh dari website Bursa Efek Indonesia.

Dalam penentuan sampel digunakan cara purposive sampling, Sugiyono (2010) .Pemilihan sampel atas dasar kesesuaian antara karakteristik sampel dengan kriteria pemilihan tertentu. Adapun karakteristik dan kriteria yang ditetapkan adalah sebagai berikut:

1. Perusahaan sektor Properti dan Real Estate tersebut masih terdaftar di Bursa Efek Indonesia pada Januari 2013 sampai dengan Desember 2014.

2. Data harga saham perusahaan sektor Properti dan Real Estate tersedia di Bursa Efek Indonesia pada Januari 2013 sampai dengan Desember 2014.

3. Tersedianya laporan keuangan perusahaan sektor Properti dan Real Estate di Bursa Efek Indonesia pada tahun 2013 sampai dengan Desember 2014.

Perusahaan yang menjadi populasi tersaji pada dibawah ini

Tabel Daftar Perusahaan Sektor Properti dan Real Estate

\begin{tabular}{|c|l|c|l|}
\hline No. & \multicolumn{1}{|c|}{ Nama Perusahaan } & No. & \multicolumn{1}{|c|}{ Nama Perusahaan } \\
\hline 1 & ASRI (Alam Sutera Realty Tbk) & 17. & JRPT (Jaya Real Property Tbk) \\
\hline 2 & BCIP (Bumi Citra Permai Tbk) & 18. & KIJA (Kawasan Industri Jabeka Tbk) \\
\hline 3. & BIPP (Bhuwanatala Indah Permai Tbk) & 19. & KPIG (Global Land Development Tbk) \\
\hline 4. & BKDP (Bukit Darmo Property Tbk) & 20. & LAMI (Lamicitra Nusantara Tbk) \\
\hline 5. & BKSL (Sentul City Tbk) & 21. & LCGP (Laguna Cipta Griya Tbk) \\
\hline
\end{tabular}

32 | Jurnal Aset (Akuntansi Riset) Vol.7 | No.1 | 2015 


\begin{tabular}{|c|l|c|l|}
\hline No. & \multicolumn{1}{|c|}{ Nama Perusahaan } & No. & \multicolumn{1}{|c|}{ Nama Perusahaan } \\
\hline 6. & BSDE (Bumi CitrSerpong Damai Tbk) & 22. & LPCK (Lippo Cikarang Tbk) \\
\hline 7. & CTRA (Ciputra Development Tbk) & 23. & LPKR (Lippo Karawaci Tbk) \\
\hline 8. & CTRP (Ciputra Property Tbk) & 24. & MDLN (Modernland Reality Ltd. Tbk) \\
\hline 9. & CTRS (Ciputra Surya Tbk) & 25. & MKPI (Metropolitan Kentjana Tbk) \\
\hline 10. & DART (Duta Anggada Reality Tbk) & 26. & OMRE (Indonesia Prima Property Tbk) \\
\hline 11. & DILD (Intiland Development Tbk) & 27. & PWON (Pakuwon Jati Tbk) \\
\hline 12. & DUTI (Duta Pertiwi Tbk) & 28. & RBMS (Ristia Bintang Tbk) \\
\hline 13. & ELTY (Bakrieland Development Tbk) & 29. & RDTX (Roda Vivatex Tbk) \\
\hline 14. & $\begin{array}{l}\text { GMTD (Goa Makassar Tourism } \\
\text { Development Tbk) }\end{array}$ & 30. & SCBD (Danayasa Arthatama Tbk) \\
\hline 15. & GPRA (Perdana Gapuraprima Tbk) & 31. & SMDM (Suryamas Dutamakmur Tbk) \\
\hline 16. & $\begin{array}{l}\text { JIHD (Jakarta International Hotels and } \\
\text { Development Tbk) }\end{array}$ & 32. & SMRA (Summarecon Agung Tbk) \\
\hline
\end{tabular}

Sumber: Bursa Efek Indonesia

Model analisis data dilakukan secara kuantitatif dengan menggunakan analisis regresi berganda, korelasi dan determinasi .Tujuannya adalah untuk menetapkan apakah variabel-variabel independen mempunyai pengaruh terhadap variabel dependen. Pengujian asumsi klasik dilakukan untuk memberikan kepastian bahwa persamaan regresi yang didapatkan memiliki ketepatan dalam estimasi, tidak bias dan konsisten. Uji asumsi klasik yang digunakan abtara lain: uji multikolinearitas, uji autokorelasi, uji heteroskedastisitas, uji normalitas.

\section{HASIL DAN PEMBAHASAN}

\section{Analisis Regresi}

Untuk mengetahui hubungan fungsional antara variabel X (Inflasi, BI Rate dan Nilai Tukar Dollar) dan variabel Y (Harga Saham Sektor Properti) digunakan analisis regresi linear berganda.

Coefficients $^{\mathrm{a}}$

\begin{tabular}{|c|c|c|c|c|c|c|c|c|c|c|c|c|}
\hline \multirow[t]{2}{*}{ Model } & \multicolumn{2}{|c|}{$\begin{array}{c}\text { Unstandardized } \\
\text { Coefficients }\end{array}$} & \multirow{2}{*}{$\begin{array}{c}\text { Standar } \\
\text { dized } \\
\text { Coeffici } \\
\text { ents } \\
\text { Beta }\end{array}$} & \multirow[b]{2}{*}{$\mathrm{t}$} & \multirow[b]{2}{*}{ Sig. } & $\begin{array}{r}95,0 \% \mathrm{C} \\
\text { Interva }\end{array}$ & $\begin{array}{l}\text { nfidence } \\
\text { for B }\end{array}$ & \multicolumn{3}{|c|}{ Correlations } & \multicolumn{2}{|c|}{ Collinearity Statistics } \\
\hline & B & $\begin{array}{l}\text { Std. } \\
\text { Error }\end{array}$ & & & & $\begin{array}{l}\text { Lower } \\
\text { Bound }\end{array}$ & $\begin{array}{l}\text { Upper } \\
\text { Bound }\end{array}$ & $\begin{array}{l}\text { Zero- } \\
\text { order }\end{array}$ & $\begin{array}{c}\text { Parti } \\
\text { al }\end{array}$ & Part & $\begin{array}{l}\text { Toler } \\
\text { ance }\end{array}$ & VIF \\
\hline (Constant) & $\begin{array}{r}1434,3 \\
09\end{array}$ & $\begin{array}{r}710,60 \\
8\end{array}$ & & $\begin{array}{r}2,01 \\
8\end{array}$ & ,181 & $\begin{array}{r}- \\
1623,19\end{array}$ & $\begin{array}{r}4491,81 \\
0\end{array}$ & & & & & \\
\hline inflasi & $-5,920$ & 17,080 &,- 214 &, 347 &, 762 & $-79,409$ & 67,569 &,- 616 & - & $\begin{array}{r}- \\
, 119\end{array}$ &, 309 & 3,235 \\
\hline sukubunga & $\begin{array}{r}- \\
81,594\end{array}$ & 63,721 & $-1,386$ & $\begin{array}{r}12,8 \\
0\end{array}$ &, 329 & $\begin{array}{r}- \\
355,763\end{array}$ & 192,576 &,- 336 & $\begin{array}{r}- \\
, 671\end{array}$ & $\begin{array}{r}- \\
, 439\end{array}$ & 100 & 9,960 \\
\hline nilaitukardollar &,- 075 & ,043 & $-1,406$ & $\begin{array}{r}17,3 \\
1\end{array}$ & ,226 &,- 260 & ,111 &,- 119 & $\begin{array}{r}- \\
, 774\end{array}$ & $\begin{array}{r}- \\
, 594\end{array}$ &, 178 & 5,603 \\
\hline
\end{tabular}

Persamaan analisis regresi linier berganda

$$
\begin{gathered}
\mathrm{Y}=1434,309-5,920 \mathrm{X}_{1}- \\
81,594 \mathrm{X}_{2}-0,075 \mathrm{X}_{3}
\end{gathered}
$$

Persamaan garis linier berganda di atas mempunyai arti sebagai berikut :

a. Jika infalsi $\left(X_{1}\right)$, suku bunga $\left(X_{2}\right)$ dan nilai tukar dollar $\left(\mathrm{X}_{3}\right)=\mathrm{Rp}$. 0, maka besarnya 
harga saham (Y) sebesar nilai konstanta yaitu Rp.1434,309

b. Jika infalsi $\left(X_{1}\right)=1$, suku bunga $\left(X_{2}\right)=0$ dan nilai tukar dollar $\left(X_{3}\right)=0$, maka setiap penambahan inflasi $\left(X_{l}\right)$ sebesar $=$ Rp. 1 akan mengurangi harga saham sebesar nilai Rp. 5,920

c. Jika infalsi $\left(X_{1}\right)=0$, suku bunga $\left(X_{2}\right)$ $=1$ dan nilai tukar dollar $\left(X_{3}\right)=0$, maka setiap penambahan suku bunga
$\left(X_{2}\right)$ sebesar $=$ Rp. 1 akan mengurangi harga saham sebesar nilai Rp. 81,594

d. Jika infalsi $\left(X_{1}\right)=0$, suku bunga $\left(X_{2}\right)=0$ dan nilai tukar dollar $\left(X_{3}\right)=1$, maka setiap penambahan nilai tukar dollar $\left(\mathrm{X}_{3}\right)$ sebesar $=$ Rp. 1 akan mengurangi harga saham sebesar nilai Rp. 0,075

Koefisien korelasi, koefisien determinasi

Model Summary

\begin{tabular}{|c|c|c|c|c|c|c|c|c|c|}
\hline \multirow{2}{*}{$\begin{array}{c}\text { Mode } \\
1\end{array}$} & \multirow[b]{2}{*}{$\mathrm{R}$} & \multirow[b]{2}{*}{$\begin{array}{c}\mathrm{R} \\
\text { Square }\end{array}$} & \multirow[b]{2}{*}{$\begin{array}{c}\text { Adjusted R } \\
\text { Square }\end{array}$} & \multirow{2}{*}{$\begin{array}{l}\text { Std. Error } \\
\text { of the } \\
\text { Estimate }\end{array}$} & \multicolumn{5}{|c|}{ Change Statistics } \\
\hline & & & & & $\begin{array}{l}\text { R Square } \\
\text { Change }\end{array}$ & $\begin{array}{c}\mathrm{F} \\
\text { Change }\end{array}$ & df1 & df 2 & Sig. F Change \\
\hline 1 & $875^{\mathrm{a}}$ & ,765 & ,412 & 21,24015 & ,765 & 2,167 & 3 & 2 & ,331 \\
\hline
\end{tabular}

a. Predictors: (Constant), nilaitukardollar, inflasi, sukubunga

Berdasarkan tabel interpretasi dapat diketahui bahwa hasil perhitungan koefisien korelasi sebesar 0,875 mempunyai arti bahwa terdapat hubungan yang sangat kuat antara inflasi, suku bunga dan nilai tukar dollar dengan harga saham.

Dari nilai diatas diperoleh koefisien determinasi sebesar 0.765 dengan indeks determinasi sebesar $76,5 \%$. Nilai ini berarti bahwa sebesar $76,5 \%$ variabilitas mengenai harga saham dapat ditpengaruhi oleh variabel inflasi, suku bunga dan nilai tukar dollar sedangkan sisanya $23,5 \%$ dipengaruhi oleh variabel lain di luar variabel tersebut.

\section{Uji T (parsial)}

Pengujian untuk variabel $\mathrm{X}_{1}$

Terlihat bahwa nilai t hitung $0,347<\mathrm{t}$ tabel 2,776 ini berarti bahwa inflasi tidak berpengaruh signifikan terhadap harga saham.

\section{Pengujian untuk variabel $\mathbf{X}_{2}$}

Terlihat bahwa nilai $\mathrm{t}$ hitung 12,80 > $\mathrm{t}$ tabel 2,776 ini berarti bahwa suku bunga berpengaruh signifikan terhadap harga saham.

\section{Pengujian untuk variabel $\mathrm{X}_{3}$}

Terlihat bahwa nilai $\mathrm{t}$ hitung 17,31 > t tabel 2,776 ini bahwa nilai tukar dollar berpengaruh signifikan terhadap harga saham.

\section{Uji F (uji simultan)}

Setelah dilakukan uji asumsi klasik, pada bagian ini akan dilakukan pengujian secara simultan menggunakan uji $\mathrm{F}$. Uji $\mathrm{F}$ dilakukan untuk mengetahui ada atau tidaknya pengaruh antara inflasi, suku bunga BI rate dan nilai tukar dollar AS terhadap harga saham perusahaan sektor properti dan real estate secara bersama-sama (simultan). 
ANOVA $^{b}$

\begin{tabular}{|r|r|r|r|r|r|}
\hline \multicolumn{1}{|c|}{ Model } & Sum of Squares & df & Mean Square & F & \multicolumn{1}{c|}{ Sig. } \\
\hline $1 \quad$ Regression & 2933,489 & 3 & 977,830 & 2,167 & \\
Residual & 902,288 & 2 & 451,144 & & \\
Total & 3835,777 & 5 & & & \\
\end{tabular}

a. Predictors: (Constant), nilaitukardollar, inflasi, sukubunga

b. Dependent Variable: hargasaham

Dari tabel diatas diperoleh $\mathrm{F}$ hitung sebesar 2,167 sedangkan $\mathrm{F}$ tabel sebesar 1,53125 maka F hitung > F tabel ,maka dapat disimpulkan bahwa seluruh variabel yaitu Inflasi, Suku Bunga BI rate dan Nilai Tukar Dollar AS secara bersama-sama mempengaruhi variabel Harga Saham Perusahaan Sektor Properti dan Real Estate secara signifikan.

\section{Pembahasan Analisis Verifikatif untuk menjelaskan signifikan}

Hasil penelitian yang dilakukan dengan menggunakan uji F-statistik menunjukkan bahwa inflasi, suku bunga BI rate dan Nilai Tukar Dollar AS secara bersama-sama mempengaruhi harga saham perusahaan sektor properti dan real estate secara signifikan. Sedangkan besaran koefisien determinasi $\left(\mathrm{R}^{2}\right)$ sebesar 0,765, Hal ini menunjukkan bahwa inflasi, suku bunga BI rate dan nilai tukar dollar AS mampu mempengaruhi variabel harga saham Perusahaan Sektor Properti dan Real Estate sebesar 76,5\%. sedangkan sisanya sebesar 23,5\% dijelaskan faktor-faktor lain.Hal ini berarti masih terdapat faktor-faktor lain diluar variabel inflasi, suku bunga BI rate dan nilai tukar dollar AS. Faktor ekonomi makro lain yang bisa saja berpengruh terhadap harga saham diantaranya Produk Domestik Bruto, Anggaran defisit, Investasi swasta, neraca perdagangan dan pembayaran.Ada pula faktor fundamental perusahaan yang bisa dilihat dari Return On Investment (ROI), dan Earning Per Share (EPS) serta faktor lainnya yang mempunyai pengaruh terhadap harga saham.

Sedangkan hasil perhitungan uji tstatistik secara parsial diperoleh bahwa inflasi tidak berpengaruh secara signifikan terhadap harga saham.Hasil tersebut sejalan dengan hasil penelitian terdahulu yang dilakukan oleh Permana (2009) yang hasilnya "Inflasi tidak berpengaruh secara signifikan terhadap harga saham".Hal tersebut berarti tidak menguatkan teori yang diungkapkan oleh Tandelilin (2010), peningkatan inflasi secara relatif merupakan sinyal negatif bagi pemodal di pasar modal. Hal ini berarti, jika inflasi naik maka akan menurunkan harga saham dan sebaliknya jika inflasi menurun akan menaikkan harga saham. Kondisi inflasi yang terjadi pada periode yang diteliti masih berada di angka yang tidak terlalu tinggi sehingga investor pun tetap berinvestasi dan membeli saham perusahaan sektor properti dan real estate. Sehingga walaupun inflasi mengalami kenaikan, harga saham perusahaan sektor properti dan real estate tetap memberikan nilai yang tinggi sehingga return yang didapatkan pun menarik bagi para investor.

Berdasarkan hasil perhitungan uji tstatistik secara parsial diperoleh bahwa suku bunga $\mathrm{BI}$ rate berpengaruh signifikan terhadap harga saham. Pengaruh suku bunga BI rate terhadap harga saham sebesar $12.8>2,776$ ,yang artinya suku bunga BI rate memiliki pengaruh yang negatif terhadap harga saham. Hal ini sejalan dengan penelitian terdahulu yang dilakukan oleh Raharjo (2011) terdapat pengaruh yang signifikan antara suku bunga dan harga saham. Dengan teori pengaruh suku bunga dengan harga saham seperti yang dikemukakan oleh Tandelilin (2010), tingkat bunga yang tinggi merupakan sinyal negatif terhadap harga saham. Dimana jika suku bunga mengalami kenaikan maka harga saham akan turun dan sebaliknya jika suku bunga turun maka harga saham akan meningkat. Suku 
bunga $\mathrm{BI}$ rate menjadi patokan bagi investor untuk mengestimasi apakah nantinya suku bunga bank seperti suku bunga deposito atau suku bunga kredit akan naik atau turun.

Berdasarkan hasil uji t-statistik menunjukkan nilai tukar dollar AS berpengaruh terhadap harga saham dengan nilai t-statistik sebesar 17,31 lebih besar daripada t-tabel pada tingkat signifikansi $5 \%$ sebesar 2,667.

Menurut teori yang diungkapkan oleh Tandelilin (2010), nilai tukar merupakan sinyal positif, artinya jika nilai tukar terapresiasi maka harga saham akan meningkat begitu juga sebaliknya jika nilai tukar mengalami depresiasi maka harga saham akan mengalami penurunan. Menguat dan melemahnya nilai tukar suatu Negara menandakan keadaan ekonomi Negara tersebut. Jika nilai mata uang sedang menguat menandakan keadaan ekonomi Negara tersebut sedang baik, dimana akan banyak investor yang menanamkan modalnya di Negara tersebut juga menanamkan modalnya di pasar modal. Pada hasil penelitian diperoleh hasil yang negatif antara nilai tukar dollar AS dalam bentuk rupiah terhadap harga saham, artinya nilai dollar AS yang menurun akan menaikkan harga saham dalam hal ini berarti nilai rupiah menguat dan menyebabkan harga saham

\section{SIMPULAN}

Terdapat pengaruh yang signifikan dari inflasi, suku bunga BI rate dan nilai tukar dollar AS secara simultan terhadap harga saham perusahaan sektor properti dan real estate di Bursa Efek Indonesia periode Januari 2013 Desember 2014, dimana :

Tidak terdapat pengaruh yang signifikan secara parsial variabel inflasi terhadap harga saham perusahaan sektor properti dan real estate di Bursa Efek Indonesia periode Januari 2013 - Desember 2014.

Terdapat pengaruh yang signifikan secara parsial suku bunga BI rate terhadap harga saham perusahaan sektor properti dan real estate di Bursa Efek Indonesia periode Januari 2013 - Desember 2014. Dari hasil pengujian diperoleh bahwa secara parsial, variabel suku bunga BI rate menunjukan meningkat artinya terdapat pengaruh yang positif sebaliknya nilai dollar AS yang meningkat akan membuat harga saham menjadi turun dalam hal ini berarti nilai tukar rupiah melemah dan membuat harga saham menurun, dimana pengaruh yang terjadi sesuai dengan teori yang ada.

Kondisi rupiah yang menguat menjadi pertimbangan para investor dalam membeli saham, apabila nilai rupiah melemah investor cenderung akan menjual saham atau tidak membeli saham karena menghindari resiko yang ada, dan bagi investor atau orang yang memiliki uang dalam jumlah dollar maka mereka akan menjual dollarnya karena harga dollar yang sedang menguat sehingga harga saham pun mengalami penurunan. Melemahnya nilai tukar rupiah terhadap dollar AS juga berdampak terhadap meningkatnya biaya impor bahan baku dan peralatan yang dibutuhkan perusahaan sehingga mengakibatkan meningkatnya biaya produksi, atau dengan kata lain melemahnya nilai tukar rupiah terhadap dollar AS memiliki pengaruh negatif terhadap ekonomi nasional yang pada akhirnya menurunkan kinerja saham di pasar saham dan harga saham pun menurun.

adanya kausalitas berlawanan atau negatif dengan harga saham. Artinya apabila suku bunga BI rate meningkat maka harga saham perusahaan sektor properti dan real estate akan turun, Begitu pula sebaliknya .

Terdapat pengaruh yang signifikan secara parsial nilai tukar terhadap harga saham perusahaan sektor properti dan real estate di Bursa Efek Indonesia periode Januari 2013 - Desember 2014. Dari hasil pengujian diperoleh bahwa secara parsial, variabel nilai tukar dollar AS terhadap rupiah menunjukan adanya kausalitas berlawanan atau negatif

\section{DAFTAR PUSTAKA}

Case, Karl E. dan Ray. C Fair. 2007. PrinsipPrinsip Ekonomi, Edisi Kedelapan. Jilid 1. Jakarta: Erlangga 
Diantoro, Y. 2010. investasi dan pengolahannya. PT.Gramedia Pustaka.

\section{Jakarta.}

Gujarati, Damodar. 2006. Dasar-Dasar Ekonometrika.Jakarta: Erlangga.

Jeff Madura 2007.Keuangan Perusahaan Internasional (Buku 1) (Edisi 8) Salemba Empat

Jogiyanto, H.M. (2010). Teori Portofolio dan Analisis Investasi. Edisi Ketujuh. BPFE. Yogyakarta

Kasmir. 2008. Bank dan Lembaga Keuangan Lainnya. Edisi Revisi 2008. Jakarta: PT. RAJA GRAFINDO PERSADA.

Kewal (2012) journal ekonomia Vol 8 no 1 EISSN : $2460-1552$

Mankiw, Gregory, 2003, Teori Makro Ekonomi, Alih bahasa Imam Nurmawan, Edisi Kelima, Jakarta Erlangga.

Nazir, Moh. 2005. Metode Penelitian. Jakarta: Ghalia Indonesia

Rusdin.2005. Pasar Modal. Bandung

Sunaryah. 2004. Pengantar Pengetahuan Pasar Modal, Edisi 4, UPP AMK YKPN,.

Samsul (2006), Pasar modal dan manajemen Portofolio, Surabaya ; Erlangga

Sukirno, 2006. Makroekonomi: Teori Pengantar, Penerbit PT. Raja Grafindo Persada, Jakarta.

Salim (2010) Cara gampang bermain Saham. Visi Media. Jakarta

Sugiyono. (2010), Metode Penelitian Kuantitatif Kualitatif dan R\&D,. Alfabeta, Bandung

Tandelilin, Eduardus. 2010. Portofolio dan Investasi Teori dan Aplikasi. Edisi pertama. Yogyakarta Kanisius

Widoatmodjo (2007) cara cepat memulai investasi saham, Jakarta PT.Elex media Komputindo 